\title{
Mineralogical, Chemical, Geotechnical and Mechanical Investigations of Bafang Lateritic Fine Soils Formed on Basalts (West-Cameroon) for Road Embankment Purpose
}

\author{
William Tchungouelieu Hyoumbi ${ }^{1,2}$, Patrick Pizette ${ }^{2}$, Armand Sylvain Ludovic Wouatong ${ }^{1} \&$ Nor-Edine Abriak $^{2}$ \\ ${ }^{1}$ Department of Earth Science, University of Dschang, P.O. Box: 67 Dschang, Cameroon \\ ${ }^{2}$ Department of civil engineering and Environmental IMT Lille Douai, University of Lille, F-59000 Lille, France \\ Correspondence: William Tchungouelieu Hyoumbi, Department of civil engineering and Environmental IMT Lille \\ Douai, University of Lille, F-59000 Lille, France. E-mail: hyoumbi_willy@yahoo.fr, patrick.pizette@imt-lille- \\ douai.fr, aslwouat@yahoo.com, nor-edine.abriak@imt-lille-douai.fr
}

\author{
Received: March 17, 2018 Accepted: March 26, 2018 Online Published: May 4, 2018 \\ doi:10.5539/esr.v7n2p42 URL: https://doi.org/10.5539/esr.v7n2p42
}

\begin{abstract}
The present paper treats the relationship between geotechnical parameters and the mineralogical compositions, in order to understand the behavior of the Bafang lateritic fine soils and their efficient use as road embankment materials on the other hand. Thus, the field campaigns have permitted to distinguish two facies of Bafang lateritic fine soils: reddish and yellowish facies. The X-ray diffraction (XRD), the thermo-gravimetry analysis (TGA) and the X-ray fluorescence (XRF) have revealed that the reddish facies contents: kaolinite (53.34\% - $48.29 \%)$; hematite (16.62\% - $17.40 \%)$; gibbsite (8.26 \% - 16.54\%), ilmenite (7.6 \% - 7.98\%), quartz (1.92 \% - 4.65\%), illite (2.65\% $-1.99 \%)$ and accessories minerals as florencite $(1.45 \%)$; montmorillonite $(0.90 \%)$ and plagioclase $(0.69 \%)$; while the yellowish facies is composed of : $65.1 \%$ kaolinite, $11.2 \%$ gibbsite, $9.64 \%$ goethite, $7.02 \%$ quartz, $3.23 \%$ ilmenite and $2.08 \%$ of illite. Their Silica/sexquioxide ratios correspond to those of moderate laterite. The geotechnical and mechanical characteristics have shown that the reddish and yellowish facies are respectively silty clay and sandy silt. They are plastic to very high plastic and moderately clayey to clayey materials. Moreover, they are medium swelling to high swelling. The IBR values more than $40 \%$ and the soaked CBR values prove that these materials belong to the S4 bearing capacity class. The minimum values of UCS and Rt are respectively $1.7 \mathrm{MPa}$ and $0.17 \mathrm{MPa}$. Then, the results of geotechnical and mechanical properties combining to those of XRD, TGA and XRF have demonstrated that the fine lateritic soils with low silica/sexquioxide ratios values (less than 1.6) are suitable for road embankment.
\end{abstract}

Keyword: fine lateritic soils, chemistry and mineralogy, geotechnical and mechanical properties, road embankment, Bafang, Cameroon

\section{Introduction}

The roadway is a linear civil engineering structure, formed by the superposition of different natures of layers materials, named superstructure. The superstructure is composed from top to the bottom of: (1) paved layer, (2) base layer and (3) sub-base layer (Yoder et Witczak 1975). All of this is laid on platform, surface of the subgrade or earthworks platform surface (embankment) (SETRA-LCPC 2000). Concerning the sub-base and subgrade, they are realized with lateritic gravelly soils in Africa Sub-saharian Countries because these materials have the good bearing capacities or the good geotechnical characteristics (CEBTP 1984; Sikali and Mir Emerati 1986; Millogo et al. 2008; Kamtchueng et al. 2015; Mvindi et al. 2017; Nzabakurikiza et al. 2017; Onana et al. 2017).

Today in Cameroun, the rate of roadway is increasing. This is due to the different road construction works which are ongoing on the entire country in general and its Western region in particular. These works imply the lateritic gravelly soils uses. However, Hyoumbi et al. (2017) show that suitable lateritic gravelly soils for sub-base and sub-grade or earthworks platform surface are not much widespread in Western Cameroon Highland. The lower concentration of lateritic gravelly soils leads to their uses for realizing only the sub-base course of the road in Bafang area by the contractors companies. Thus the lateritic fine soils remain the main raw materials for realizing the roads embankments because they border the road route. For using them, only geotechnical properties based on the grain size distribution, the Atterberg limits, the methylene blue value, the references of modified proctor and 
the Californian Bearing Ratio (CBR) are carry out in the laboratory. Beyond these different tests, the CBR is the most considerable test for using a material in road work by engineers to the detriment of others. Often, the materials behave badly on the pavement structure after a short period of time. Mahalinga-Iyer and Williams (1997); Millogo et al. (2008); Camapum de Carvalho et al. (2015); Kamtchueng et al. (2015) suggest that mineralogical and chemical characteristics are also none negligible parameters for assessing the raw materials for road purposes. Moreover, the Bafang lateritic fine soils in particular, are not yet studied for road embankment purposes. The aim of this paper consists to quantify the minerals phases of Bafang fine lateritic soils from the mineralogical and chemical compositions, while showing their influence on geotechnical and mechanical, in order to broaden the data base on of these types of lateritic materials.

\section{Materials and methods}

\subsection{Methods}

The field campaigns were carried out along the route raods which connect different Bafang localities. During this campaign, different lateritic fine soils profiles were studied. These studies have interested on the descriptions of different soils profiles according to Maignien (1980). Here, thickness, color, texture, structure have considered for making differences between all the soils profiles. The color of the soil samples was determined using a Munsell color chart (1975). Then, two facies of fine lateritic soils were identified and $50 \mathrm{~kg}$ of each of them were sampling for laboratories studies.

The chemical and mineralogical analyses were realized respectively by $\mathrm{X}$ rays fluorescene (XRF) and $\mathrm{X}$ rays diffractions (XRD). They permitted to determine the chemical majors' elements in form of oxides and the different minerals phases on the other hand. Thus, 50 grammes of each soil facies sample were dried at $40^{\circ} \mathrm{C}$ during $72 \mathrm{~h}$. Then, they were crushed and sieved on $80 \mu \mathrm{m}$ mesh. Finally, 10 grammes were used to realise both analyses. They were performed on BUCKER AXS D8 ADVANCE using $\mathrm{Cu} \mathrm{K} \alpha$ radiation $(\mathrm{K} \alpha=1.78 \ddot{\mathrm{A}})$. The settings are $40 \mathrm{KV}$, $40 \mathrm{~mA}$ voltage and the acquisition domain is $2 \Theta\left(1^{\circ}-60^{\circ}\right.$ range $)$ at a scanning speed of $5^{\circ} / \mathrm{min}$. The confirmations of clayey minerals phases present in the studied materials were perfomed on oriented thin section. For making the different thin sections, the methods proposed by Thiry et al. (2013), were used. Three oriented thin sections were submitted under X rays diffractions (XRD): (1) none treated oriented thin sections; (2) treated oriented thin section by heating at $550^{\circ} \mathrm{C}$ et (3) treated oriented thin section by ethylene glycol. The determinations of different minerals phases were completed by the thermogravimetry analysis (TGA). It consists to heat 2 grammes of materials containing only particles less than $80 \mu \mathrm{m}$, at around $1000^{\circ} \mathrm{C}$ in temperature. The mass losses were measured at each $4^{\circ} \mathrm{C}$ to $5^{\circ} \mathrm{C}$ temperature range by minute. The results obtained, have allowed drawing the thermogravimetric curves of different samples. The minerals of each sample were identified according to the proportions of mass losses at a precise temperature range. The combinations of chemical data from $\mathrm{X}$ rays fluorescence analysis with the XRD and TG analyses of natural samples powders and the XRD of the oriented thin sections on the other hand, permitted to calculate the normative proportions of each mineral phase.

For determining geotechnical characteristics, the french tests specifications were used. The grain size analysis was performed using the laser device under humid condition. Atterberg limits were used to determine the plasticity index of the studied materials. The liquid limit was determined using the Casagrande apparatus while plastic limit was carried out on the rods of $15 \mathrm{~mm}$ length and about $3 \mathrm{~mm}$ of thickness according to the NF P94-051 (1993) specification. According to that specification, the plasticity index is given by $\mathrm{Eq}(1)$ :

$$
\mathrm{I}_{\mathrm{P}}=\mathrm{W}_{\mathrm{L}}-\mathrm{W}_{\mathrm{P}}(1) \text {; }
$$

where $\mathbf{I}_{\mathbf{P}}$ is the plasticity index; $\mathbf{W}_{\mathbf{L}}$ is the liquid limit and $\mathbf{W}_{\mathbf{P}}$ represents the plastic limit. According to the standard NF P 94-068 (1998), the methylene blue value (MBV) was obtained on the different samples. It permits to measure the degree of activity of fine particles $\left(\mathrm{A}_{\mathrm{CB}}\right)$ in a material from the determination of clayey fraction. To complete the physical parameters identification, the organic matter rates were determined by calcination in oven at $450^{\circ} \mathrm{C}$ (XP P94-047 1998). The modified compaction test was permitted to determine the optimum moisture content (OMC) and the maximum dry density (MDD), based on the specification NF P94-093 (1999). The OMC and the MDD parameters contribute to realize the immediate bearing ratio and the soaked CBR test in proctor mould and CBR mould respectively, according to the standard NF P94-078 (1997). Thus, the immediate bearing ratio (IBR) values were obtained by punching with automatic press of $150 \mathrm{KN}$ load. This load is used because the load of the recommended axle tree is $130 \mathrm{KN}$ and the immediate bearing ratio result permit to measure the resistance of materials against the load of vehicles traffic during the road constructions works. While the CBR test after 4 days of soaking, was allowed to obtain the bearing capacity index values at $95 \%$ of compactness (CBR) by punching with the automatic press of $50 \mathrm{KN}$ load. The compressive strength test was performed by applying a vertical pressure with $150 \mathrm{KN}$ load automatic press on cylindrical specimens (diameter $=5 \mathrm{~cm}$, height $=10 \mathrm{~cm})(\mathrm{NF}$ P 94- 
420 2000). The cylindrical specimens were compacted in steel mould at modified CBR test conditions by a static press. Also, the indirect tensile test followed the same principle as the compression test, but the specimens were positioning transversely (NF P 94-422 2001). Before submitting the specimen to compressive tests and indirect tensile test, they were kept for seven, fourteen and twenty eight days for curing at $20^{\circ} \mathrm{C}$ air conditioning which is the annual temperature condition of the study area. The tensile strength is obtained by the diametrical compressive test (NF P98 232-3 2001) using Eq (2):

$\mathrm{Rt}=0.8 \mathrm{Rtb}(2)$

\subsection{Materials}

\subsubsection{Geographical Setting and Studied Materials Location}

The fine lateritic soils are studied materials, sampling in Bafang area. Geographically, it is located within the Western Cameroon Highland. It is bounded by $05^{\circ} 05^{\prime} 02,96^{\prime \prime}$ to $05^{\circ} 09^{\prime} 07,40^{\prime \prime}$ North as latitudes and the meridian $10^{\circ} 08^{\prime} 03,70^{\prime \prime}$ to $10^{\circ} 13$ '24,44'East (Fig. 1). On the administrative point of view, the study area belongs to Bafang subdivision which is located at Western Cameroon region. It is formed of villages as Bafang, Babone, BaboutcheuNgaleu, Bankondji and Bassap; which are connected by unpaved road and track network in asphalting work project (Fig. 1). The hydrography of the area shows a dendritic network. The climate is cameroonieen equatorial type, influenced by topography and monsoon wind. This type of climate is responsible to the formation of lateritic soils. Along the unpaved road routes of the studied area, two lateritic fine soils facies were identified: reddish facies (LA1 and LA2) and yellowish facies (LA3) (Fig. 2). These facies represent the minerals horizons of the lateritic soils profiles which are used as road embankment materials. Different morphological features of lateritic fine soils profiles were identified at points coordinates in Meter degree: 629659.0E - 564282.9 N; 633013.6 E - 566813.9 $\mathrm{N}$ and $627730.6 \mathrm{E}-568059.3 \mathrm{~N}$ corresponding respectively for LA1, LA2 and LA3. The fine soils profiles LA1 and LA2 are reddish and LA3 profile of the yellowish in macroscopic view.

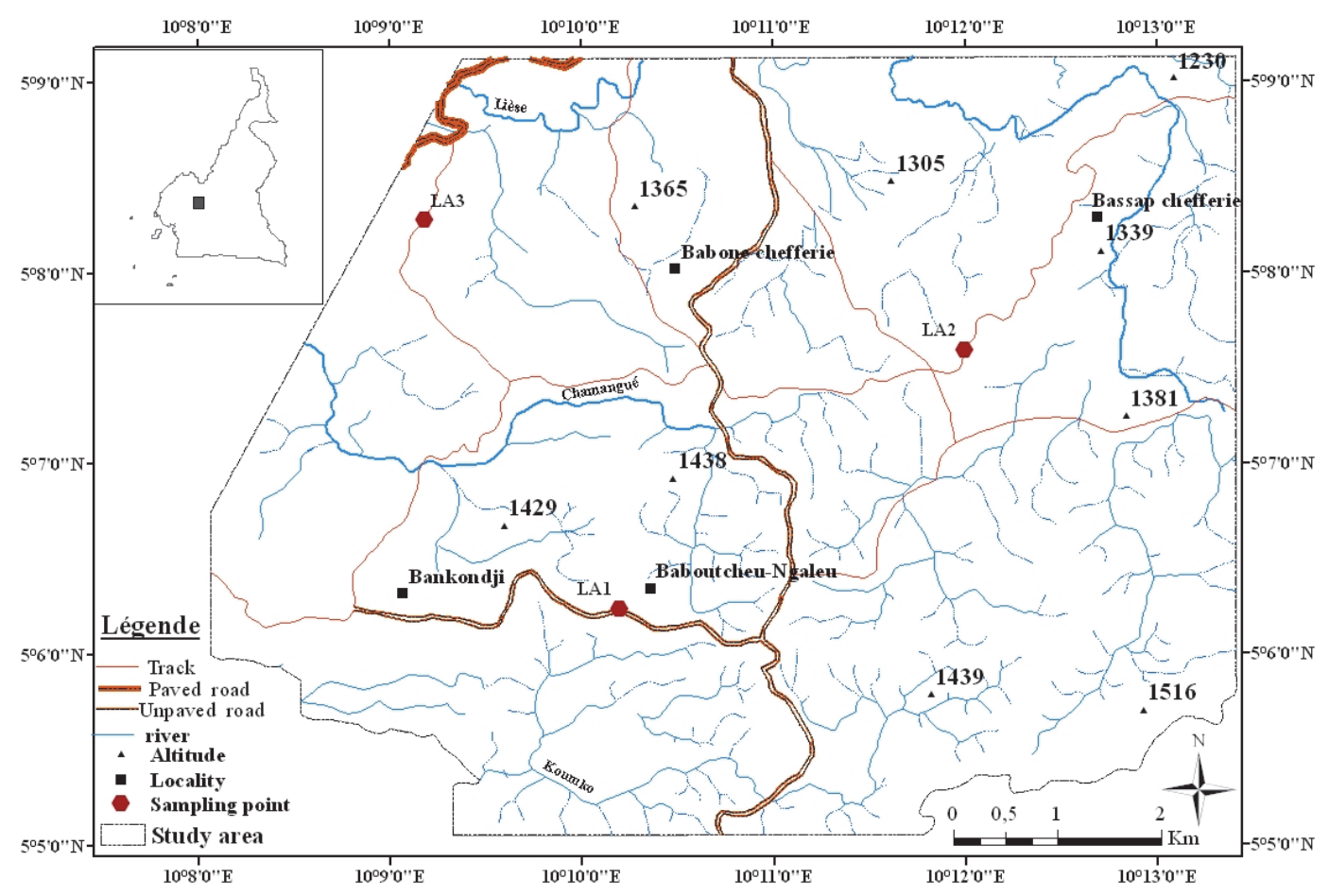

Figure 1. Studied area and sampling map

\subsubsection{Features of the Studied Materials on the Field}

Concerning the reddish lateritic fine soils profiles, the thickness of mineral horizon (horizon B) are more than 200 $\mathrm{cm}$ for LA1 and more than $104 \mathrm{~cm}$ for LA2 (Fig. 2A). Their colours are dark red (2,5YR3/6) and dark brown red (5YR3/3) respectively for LA1and LA2. The smallest nodules in size, are scattered within the horizon. Their texture is silty-clayey. This part of soil profile is under the organic mineral horizon (horizon A). Their color is dark brown $(7,5$ YR4/6). The thickness of the horizon B is about $15 \mathrm{~cm}$ for LA1 and $26 \mathrm{~cm}$ for LA2. 
As the reddish lateritic fine soils profile, the yellowish lateritic fine soils profile is observed on the road route and is the profile of loose materials. (Fig. 2 B). His mineral horizon (horizon B) is about $130 \mathrm{~cm}$ of thickness. It is an orange yellow horizon (10YR7/8), with some nodules. It is polyhedral structure and its texture is sandy clayey. It is characterised by dessication crack. Near to top part, the intensity of the coloration orange yellow reduise and pass progressively to brown yellowish. This materialise the transition zone with the organic mineral called horizon A, brown yellowish $(10 \mathrm{YR} / 6)$ in colour.
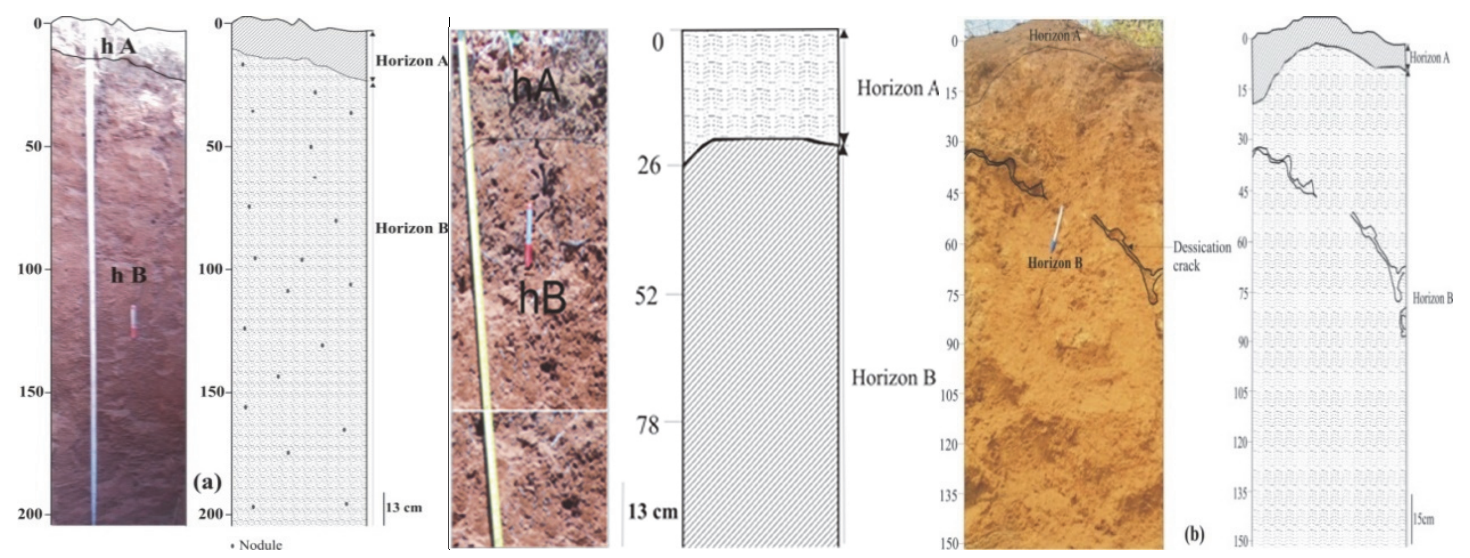

(a) Reddish facies profiles LA1 and LA2 (b) Yellowish facies profile (LA3)

Figure 2. Fine lateritic soils profiles

\section{Results}

\subsection{Mineralogical and Chemical Composition}

\subsubsection{Mineralogical Characteristics}

The X-rays diffraction spectra (Fig. 3) of the bulk materials testify their difference through the minerals phases' compositions. The LA1 is composed of main minerals phases such as kaolinite, hematite, gibbsite, ilmenite and quartz. Concerning the LA2, their minerals components are kaolinite, hematite, gibbsite ilmenite and quartz. While, the minerals phases of the yellowish facies are illite, kaolinite, gibbsite, goethite, quartz and ilmenite (Fig. 3). The oriented thin sections of clayey particles of natural materials and the oriented thin section treated by ethylene glycol on which the X-rays diffractions were realized, permit the identification of montmorillonite as an additional clayey mineral in LA1 and and the confirmation of the presence of illite into three studied materials. Moreover, the presence of kaolinite in the studied materials is confirmed by the disappearance of their diffractions peaks when the oriented thin sections were heated up to $550^{\circ} \mathrm{C}$ for hours (Fig. 3b; Fig. 3c and Fig. 3c). This is due to the effective dehydroxylation of kaolinite, which is transformed into metakaolinite starting at $500^{\circ} \mathrm{C}$ (Mefire et al. 2015).

Concerning the thermo-gravimetric curve (Fig.4), the total mass losses are $10.85 \% ; 13.75 \%$ and $19.19 \%$ respectively for LA1, LA2 and LA3. The mass losses below $200^{\circ} \mathrm{C}$ are $0.5 \%$ to $1 \%$ and correspond to the departure of absorbed water within the materials. Then, the second level of mass losses is between $200^{\circ} \mathrm{C}$ and $300^{\circ} \mathrm{C}$. There is due to the dehydration of gibbsite around $250^{\circ} \mathrm{C}$ (LA1 and LA2) and the amount of mass loss of LA1 (2.85\%) is less than the one of LA2 $(5.73 \%)$ at range temperature $250^{\circ} \mathrm{C}-300^{\circ} \mathrm{C}$. The mass loss near of $300^{\circ} \mathrm{C}$ for LA3 corresponds to the dehydration of goethite and gibbsite (Hajjaji et al.2001; Thiry et al. 2013). The most important mass losses are $6.49 \%$ and $13.88 \%$, for reddish facies and yellowish facies respectively. It is registered between $450^{\circ} \mathrm{C}$ to $600^{\circ} \mathrm{C}$. This temperature range is related to kaolinite dehydration (Wang et al. 2013). 

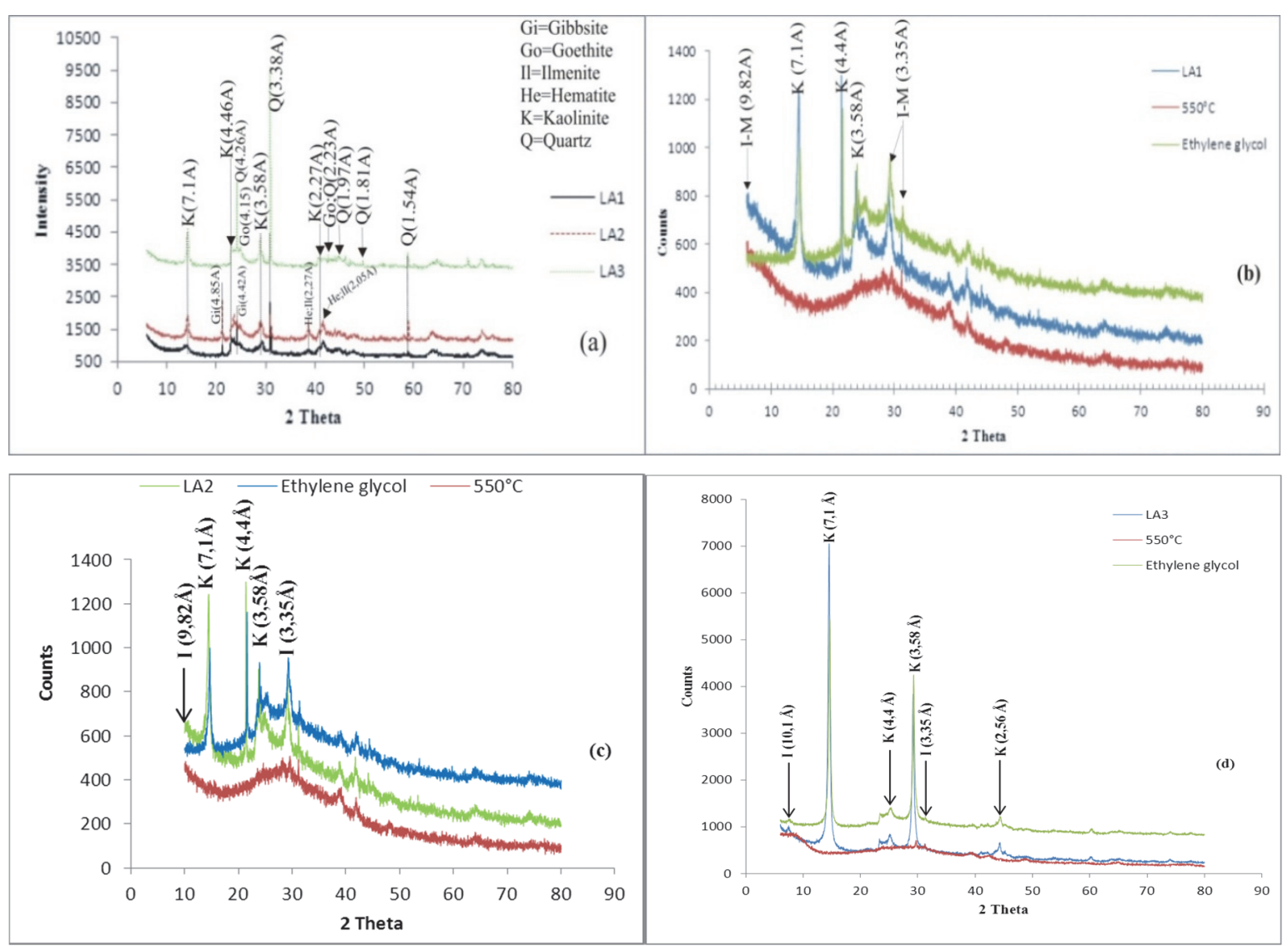

Figure 3. XRD spectra of fine lateritic soils studied: (a) XRD spectra of natural fine lateritic soil; (b) XRD spectra of treated clayey particles $(<2 \mu \mathrm{m})$ of reddish facies (LA1 and LA2) and (c) XRD spectra of treated clayed particles $(<2 \mu \mathrm{m})$ of yellowish facies (LA3)

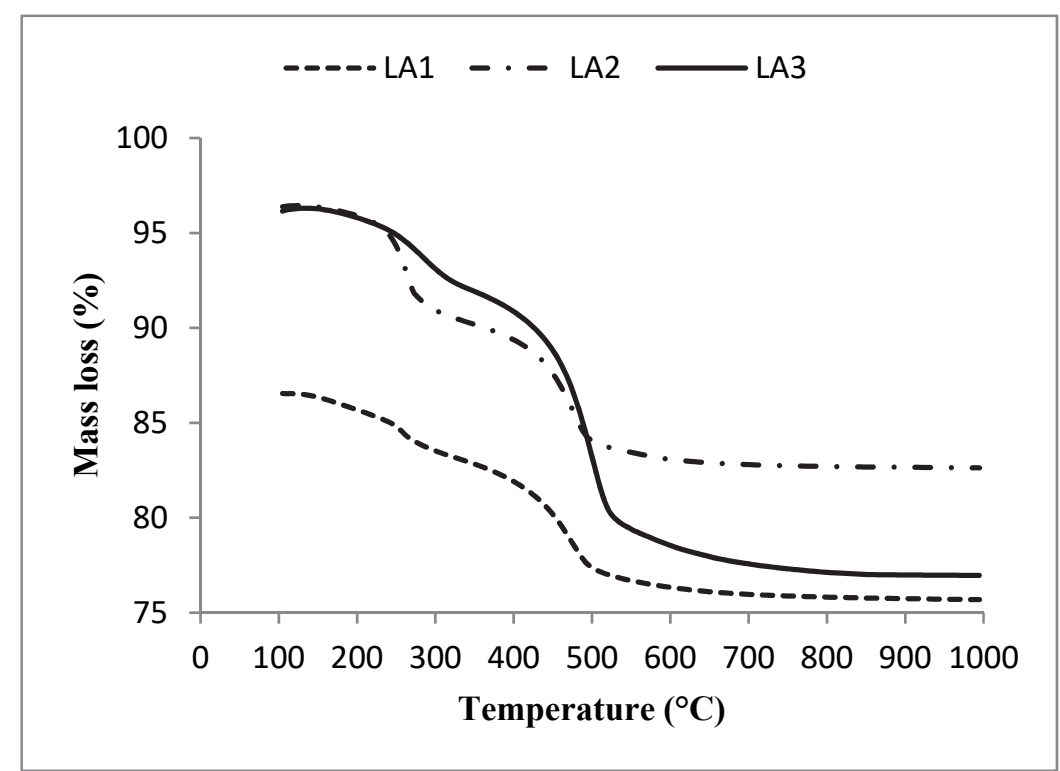

Figure 4. Thermo-gravimetric curves of studied materials

\subsubsection{Chemical Composition}

The table 1 displays the chemical compositions of each studied materials. They can be subdivided in four groups. The first one is composed of $\mathrm{MgO}, \mathrm{MnO}, \mathrm{CaO}, \mathrm{P}_{2} \mathrm{O}_{5}$. They are in fewer amounts, less than $1 \%$ in $\mathrm{LA} 1$ and are in trace form in the LA2 and LA3 materials. The second group is formed of $\mathrm{Na}_{2} \mathrm{O}$, which is none determining oxide. 
The $\mathrm{TiO}_{2}$ makes up the third group of oxides. Their amounts are $1.7 \%$ and $4.2 \%$. Finally $\mathrm{SiO}_{2}, \mathrm{Al}_{2} \mathrm{O}_{3}$ and $\mathrm{Fe}_{2} \mathrm{O}_{3}$ are the most concentrated oxides in these studied materials. In this group, the $\mathrm{SiO}_{2}$ content is more elevated than $\mathrm{Al}_{2} \mathrm{O}_{3}, \mathrm{Fe}_{2} \mathrm{O}_{3}$ and their values are $31.1 \%$ and $38.4 \%$ within $\mathrm{LA} 1$ and $\mathrm{LA} 3$; while the $\mathrm{Al}_{2} \mathrm{O}_{3}$ rate is more than those $\mathrm{SiO}_{2}$ and $\mathrm{Fe}_{2} \mathrm{O}_{3}$ in $\mathrm{LA} 2$. According to the ternary diagram $\mathrm{SiO}_{2}-\mathrm{Al}_{2} \mathrm{O}_{3}-\mathrm{Fe}_{2} \mathrm{O}_{3}$ (Wt. \%) classification, the reddish and yellowish facies are moderate laterite (Fig. 5).

Table 1. Chemical composition of the lateritic fine soils

\begin{tabular}{cccccccccccccc}
\hline Oxides & $\mathrm{SiO}_{2}$ & $\mathrm{Al}_{2} \mathrm{O}_{3}$ & $\mathrm{Fe}_{2} \mathrm{O}_{3}$ & $\mathrm{TiO}_{2}$ & $\mathrm{CaO}$ & $\mathrm{K}_{2} \mathrm{O}$ & $\mathrm{Na}_{2} \mathrm{O}$ & $\mathrm{MnO}$ & $\mathrm{MgO}$ & $\mathrm{P}_{2} \mathrm{O}_{5}$ & LOI & $\mathrm{S} / \mathrm{R}$ & $\mathrm{Total}$ \\
\hline LA1 (Wt.\%) & 31.1 & 27.4 & 20.7 & 4.0 & 0.14 & 0.12 & n.d & 0.3 & 0.33 & 0 & 15.8 & 1.3 & 99.98 \\
\hline LA2 (Wt.\%) & 25.1 & 32.7 & 20.4 & 4.2 & Trace & Trace & n.d & Trace & Trace & 0.3 & 16.2 & 0.9 & 98.9 \\
\hline LA3 (Wt.\%) & 38.4 & 33.6 & 10.1 & 1.7 & Trace & 0.13 & n.d & Trace & Trace & Trace & 16.1 & 1.6 & 100.03 \\
\hline
\end{tabular}

n.d = not detected; LOI $=$ Loss of ignition; Wt. $\%=$ weight percent; Silica/Sexquioxides ratio $\mathrm{S} / \mathrm{R}=$ $\left[\left(\mathrm{SiO}_{2} / 60\right) /\left(\mathrm{Fe}_{2} \mathrm{O}_{3} / 160+\mathrm{Al}_{2} \mathrm{O}_{3} / 102\right)\right]$

\subsubsection{Semi-Quantitative Mineralogical Determination}

The combination of mineralogical and chemical composition is used for determining the modal composition of minerals phases present in the studied materials, the semi-quantitative method of Yvon et al. (1982) was used. It stipulates that:

$$
\mathrm{T}(\mathrm{a})=\sum_{1}^{n} \operatorname{Mi} \mathrm{x} P i(a)(3)
$$

where T(a) :wt.\% of element "a" in the sample; Mi: wt.\% of the mineral "i" in the sample; and Pi(a): wt. of the element "a" in mineral "i".

The mineral reconstitution scheme is as follow:

- $\quad \mathrm{TiO}_{2}$ is used for ilmenite $\left(\mathrm{FeTiO}_{3}\right)$ (detected by $\left.\mathrm{XRD}\right)$; the $\mathrm{FeO}$ remaining quantity is attributed to hematite or to goethite depending of the sample minerals compositions;

- for calculating illite $\mathrm{KAlSi}_{3} \mathrm{O}_{10}(\mathrm{OH})_{2}$ percentage (detected by $\mathrm{XRD}$ ), $\mathrm{K}_{2} \mathrm{O}$ is used;

- $\quad \mathrm{Mg}$ is allocated to montmorillonite and $\mathrm{Ca}$ permit to calculate plagioclase.

- The thermo-gravimetric curves give the water quantity lost between $200-300^{\circ} \mathrm{C}$. These quantities are attributed to gibbsite $\left(\mathrm{Al}(\mathrm{OH})_{3}\right)$ (detected by $\left.\mathrm{XRD}\right)$ for different studied samples and goethite $(\mathrm{FeOOH})$ (detected by XRD) for LA3 sample. The amount of water lost by LA1 sample has permitted to calculate the gibbsite percentage. Concerning the LA3 sample, the XRF results testify that there is exceeding amount of $\mathrm{Al}_{2} \mathrm{O}_{3}$ oxide found in LA3 sample. This corresponds to gibbsite after determining the percentage of kaolinite.

- After using $\mathrm{Al}_{2} \mathrm{O}_{3}$ for calculating illite, gibbsite, plagioclase and montmorillonite, the $\mathrm{Al}_{2} \mathrm{O}_{3}$ remaining amount has permitted to calculate the kaolinite $\mathrm{Si}_{2} \mathrm{Al}_{2} \mathrm{O}_{5}(\mathrm{OH})_{5}$ percentage (detected by XRD).

- $\quad \mathrm{SiO}_{2}$ is used to calculate the contribution of quartz $\left(\mathrm{SiO}_{2}\right)$ (detected by XRD) after subtracting the contribution from illite, kaolinite, montmorillonite and plagioclase.

The Table 2 presents the modal composition of the minerals phases of the Bafang lateritic fine soils. It reports that clays minerals phases' content in LA1 material are about 56.92\% (illite, kaolinite, montmorillonite) and the rest of minerals concerns the oxide (ilmenite, hematite, quartz), hydroxide (gibbsite) and plagioclase. The clays minerals (kaolinite and illite) represent $50.94 \%$ of LA2 materials. While, the yellowish facies (LA3) has $67.18 \%$ of clays minerals phases (illite, kaolinite), against $31.09 \%$ of oxides (ilmenite); hydroxide (gibbsite) and oxyhydroxide (goethite). According to the amount of each mineral, kaolinite is the main clay mineral in the both studied materials (Table 2). 
Table 2. Semi-quantitative mineralogical composition of studied lateritic fine soils

\begin{tabular}{cccccccccccc}
\hline Crystallized minerals & Montmorillonite & Plagioclase & Illite & Kaolinite & Quartz & Hematite & Ilmenite & Gibbsite & Goethite & Florencite & Total \\
\hline Amount in LA1 (Wt. \%) & 0.90 & $0.69 \%$ & 1.99 & 53.34 & 4.65 & 17.40 & 7.6 & 8.26 & $/$ \\
\hline Amount in LA2 (Wt. \%) & $/$ & $/$ & 2.65 & 48.29 & 1.92 & 16.62 & 7.98 & 16.54 & $/$ \\
\hline Amount in LA3 (Wt. \%) & $/$ & $/$ & 2.08 & 65.1 & 7.02 & $/$ & 3.23 & 11.2 & 9.64 \\
\hline
\end{tabular}

\subsection{Geotechnical and Mechanical Properties of Lateritic Fine Soils}

\subsubsection{Apparent Density}

The apparent density values of the study materials are almost similar. The studied materials are less dense. Their highest value is $26.8 \mathrm{KN} / \mathrm{m}^{3}$. The poorness of nodules and the abundance of Aluminum and iron are responsible to this apparent density parameter.

\subsubsection{Grain Size Distribution}

The Bafang lateritic fine soils are loose materials with $0.2 \mathrm{~mm}$ as sizes of the largest particles. The proportions of particles included between 0.08 and $0.2 \mathrm{~mm}$ in size, are $1.5 \%$ to $28 \%$ for the studied materials (Fig. 5). The intermediate value of particles amount belonging to this range is $4.6 \%$. The sandy particles of the studied materials are $12 \% ; 30 \%$ and $62 \%$ respectively for LA1, LA2 and LA3. Concerning the clayey fractions, they are most abundant in LA1 (42\%) material than the two others. For the silt fractions, their amounts are $30 \%$ (LA3), $38 \%$ (LA2) and $46 \%$ (LA1). On grain size distribution point of view, the LA1 material is silty clay; the LA2 is clayey silt and the LA3 corresponds to sandy silt (Fig. 6). Moreover the reddish and yellowish facies contain at least $96 \%$ and $72 \%$ of fine particles $(<80 \mu \mathrm{m})$.

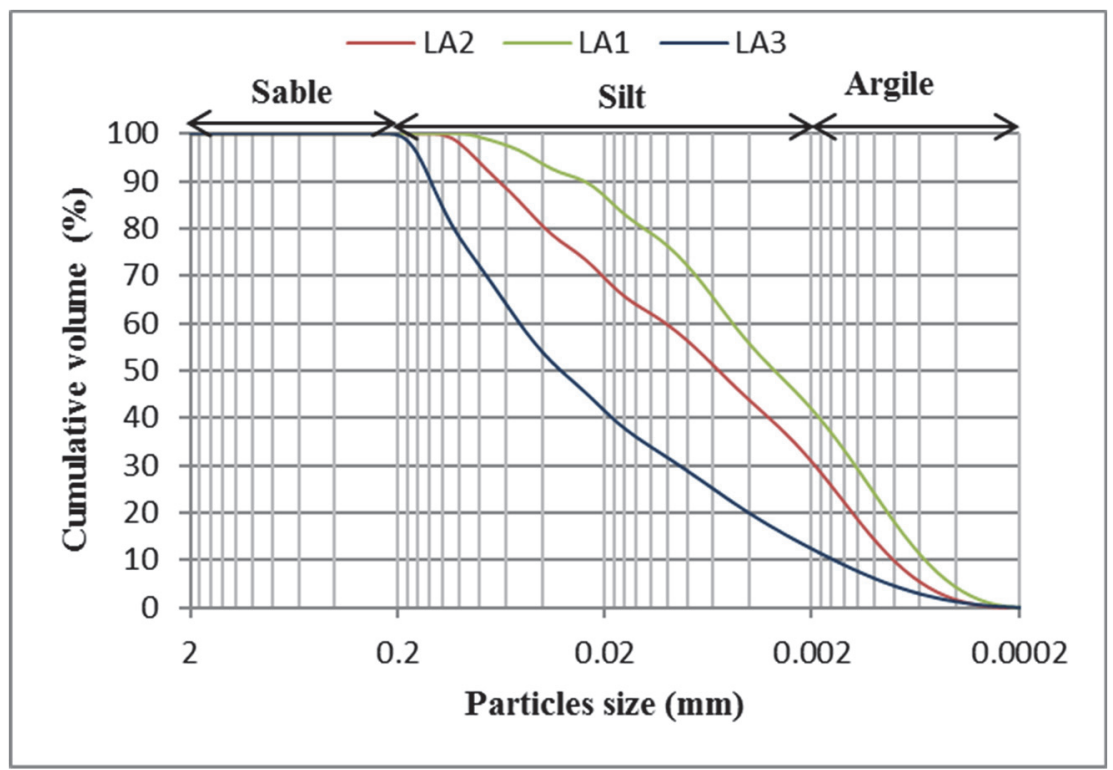

Figure 5. Grains size distribution curves of Bafang lateritic fine soils 


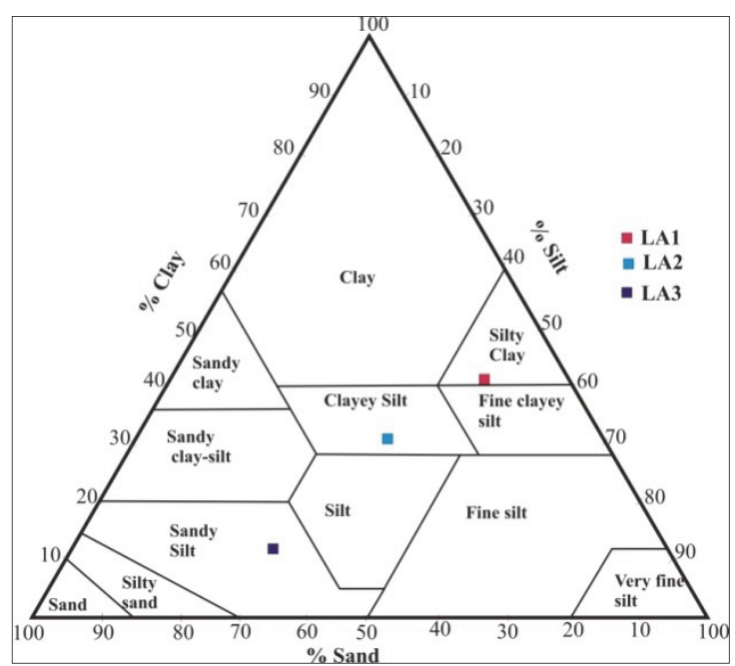

Figure 6. Ternary classification of Bafang lateritic fine soils according to their particles size distributions

\subsubsection{Activity Degree Evaluation}

The Methylene blue values (MBV) through the blue clayey activity $\left(\mathrm{A}_{\mathrm{CB}}\right)$; the organic matter values $(\mathrm{OM})$, the liquid limit values (LL) and the plasticity limit values (PL) of LA1 material are elevated than those of LA2 and LA3 materials (Table 3). The LL value is $75.8 \%$ for LA1 when they are $59 \%$ and $50 \%$ for LA2 and LA3 respectively. Then LA1 material has the highest plasticity limit value among the study materials (Table 3 ). But the results of plasticity index values prove that the materials LA2 is most plastic, with plasticity index value equal to $28.8 \%$.

Table 3. Physical characteristic of Bafang lateritic fine soils

\begin{tabular}{|c|c|c|c|c|c|c|c|c|c|}
\hline Parameters & LL $(\%)$ & PL (\%) & PI $(\%)$ & $\mathrm{OM}(\%)$ & $\operatorname{MBV}(\mathrm{g} / 100 \mathrm{~g})$ & $\mathrm{A}_{\mathrm{CB}}$ & ys & $\mathrm{I}_{\mathrm{C}}$ & Wn $(\%)$ \\
\hline Sample & & & & & & & $\left(\mathrm{KN} / \mathrm{m}^{3}\right)$ & & \\
\hline LA1 & 75.8 & 55 & 20.8 & 9.4 & 1.3 & 0,03 & 26.7 & 2.2 & 29.2 \\
\hline LA2 & 59 & 30.2 & 28.8 & 5.04 & 1.0 & 0,033 & 26.8 & 1,1 & 28.7 \\
\hline LA3 & 50 & 26.8 & 23.2 & 5.6 & 1.03 & 0,09 & 26.6 & 1.2 & 22.3 \\
\hline
\end{tabular}

Ic: consistence index; ys: Specific density; Wn: natural moisture content

\subsubsection{Mechanical Characteristics}

Figure 7 presents the modified compaction and the immediate bearing ratio parameters. The MDD values are 16.7 $\mathrm{KN} / \mathrm{m}^{3}$ (LA3) and $15.4 \mathrm{KN} / \mathrm{m}^{3}$ (LA1 and LA2). The lack of gravels can explain their MDD values. This causes the high values of the optimum moisture content (OMC). They are $19.9 \%$ for LA3 material, $25.3 \%$ for LA1 and $26.1 \%$ for LA2. From OMC and MDD, the IBR values were derived. The IBR curves exhibit the variation of their values with the rate of moisture content. After the IBR values which are $54 \% ; 49 \%$ and $44 \%$ for LA3, LA2 and LA1 materials. Even more, the most elevated soaked CBR values is $25 \%$ for LA3. These parameters values are $22 \%$ for both materials LA2 and LA1. They are approximately the half of the IBR values (Fig. 8). 


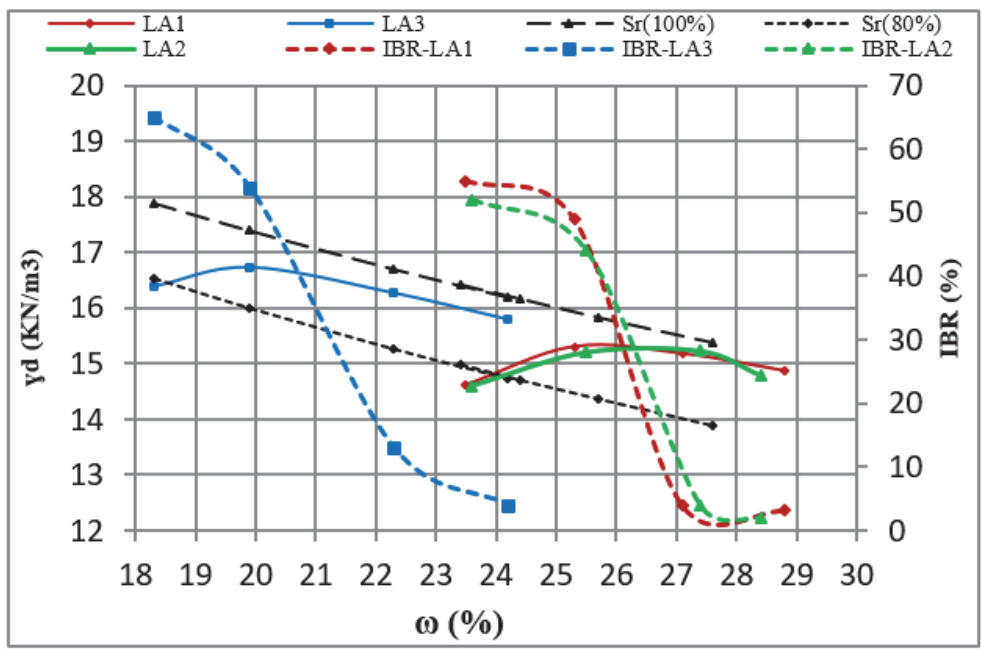

Figure 7. Modified compaction and immediate bearing ratio curves

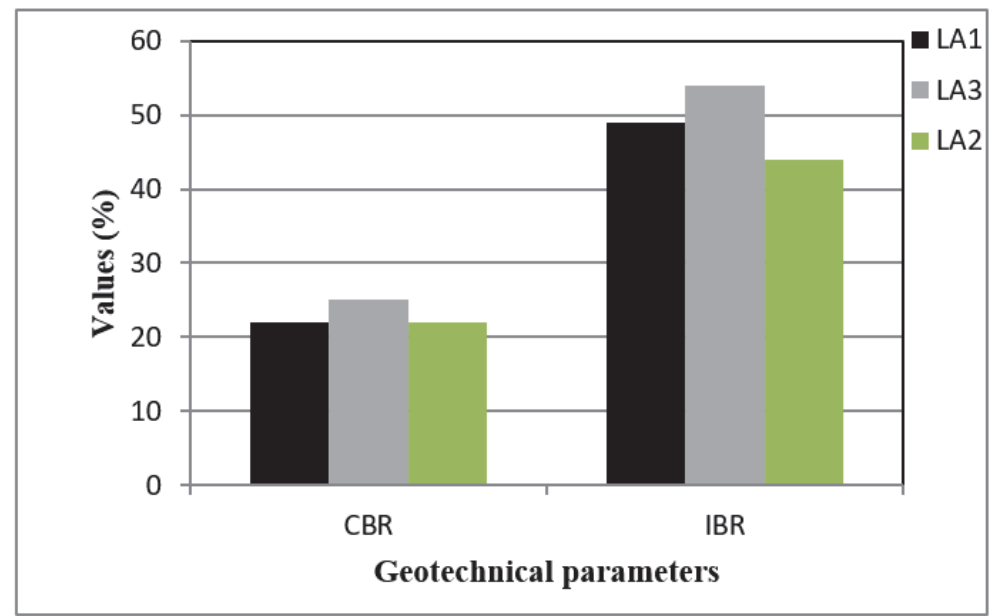

Figure 8. Soaked CBR and IBR values

Figure 9 and Table 4 reveal that the unconfined compressive strength (UCS) values of Bafang lateritic fine soils increase from seven days to twenty eight days for LA1 and LA3 materials. The maximum value of UCS for LA2 is $2.58 \mathrm{MPA}$ at fourteen days. At seven days of curing, the USC values are lowest for LA1 and LA3. While at twenty eight days, the UCS values are highest and the UCS value for LA2 at this age is lowest. With the curing days, the LA2 has weaker UCS values than those of UCS values obtained on LA1 and LA3. At seven, fourteen and twenty eight days of curing time, the UCS values are respectively $1.7 \mathrm{MPa} ; 2.3 \mathrm{MPa}$ and $3.4 \mathrm{MPa}$ for the reddish facies. Whereas, for the same curing time, the UCS values of LA3 are 3.03 MPa; $3.5 \mathrm{Mpa}$ and 4.5 MPa. Concerning the tensile strength, the minimum value is $0.17 \mathrm{MPa}$ while the maximum value is $0.26 \mathrm{MPa}$. The elevated values during curing time are registered for LA3 materials (Fig. 10 and Table 4). The maximal tensile strengths values are registered at fourteen days. 


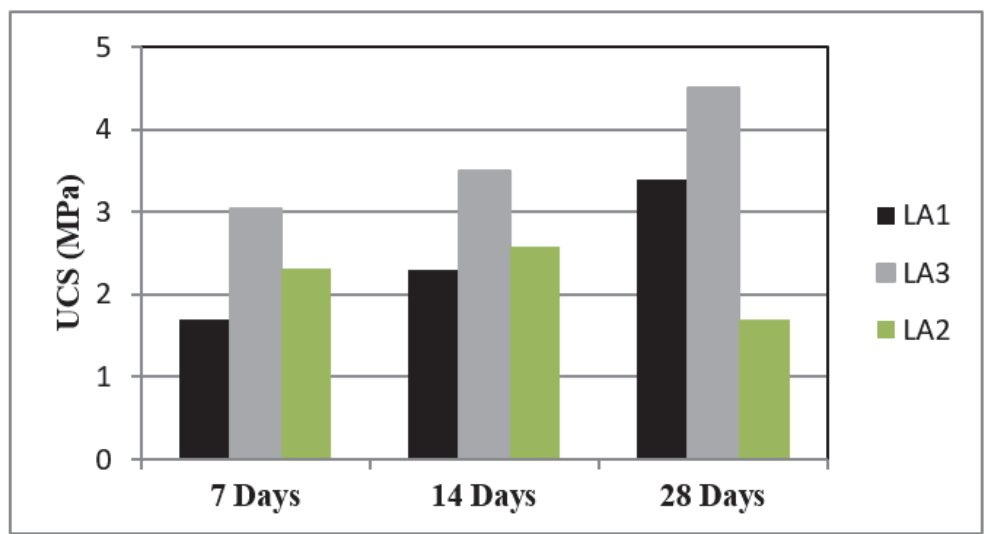

Figure 9. Variation of the compressive strength with time

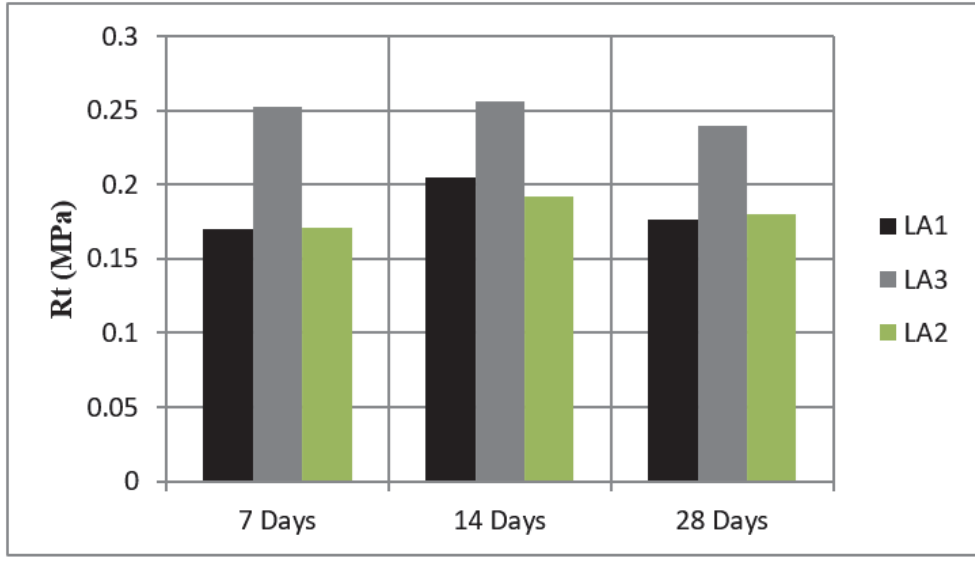

Figure 10. Evolution of the tensile strength with time

Table 4. Mechanical characteristic of Bafang lateritic fine soils

\begin{tabular}{lllll}
\hline Samples & & LA1 & LA2 & LA3 \\
\hline Parameters & Curing time & & & \\
\hline \multirow{3}{*}{ UCS (MPa) } & 7 Days & 1.7 & 2.32 & 3.03 \\
\cline { 2 - 5 } & 14 Days & 2.3 & 2.58 & 3.5 \\
\cline { 2 - 5 } & 28 Days & 3.4 & 1.69 & 4.5 \\
\hline \multirow{3}{*}{ t (MPa) } & 7 Days & 0.17 & 0.171 & 0.25 \\
\cline { 2 - 5 } & 14 Days & 0.2 & 0.192 & 0.26 \\
\cline { 2 - 5 } & 28 Days & 0.18 & 0.18 & 0.24 \\
\hline \multirow{3}{*}{ W (\%) } & 7 Days & 25.3 & 25.9 & 19.4 \\
\cline { 2 - 5 } & 14 Days & 21.9 & 22.7 & 18.5 \\
\cline { 2 - 5 } & 28 Days & 20.9 & 21.4 & 18.2 \\
\hline
\end{tabular}

$\mathrm{W}(\%)=$ moisture content in specimen

\section{Discussion}

\subsection{Mineralogical and Chemical Composition}

The Bafang studied fine soils come from the different soils profiles with the average thickness of mineral horizon more than $100 \mathrm{~cm}$. Their physical features reposing on grains size and coloration are similar to those of superficial mineral horizons observed in tropical humid zone influenced by altitude (Leumbe et al. 2005; Tematio, 2005). The main oxides components of the studied materials are $\mathrm{SiO}_{2}-\mathrm{Al}_{2} \mathrm{O}_{3}-\mathrm{Fe}_{2} \mathrm{O}_{3}$. The $\mathrm{SiO}_{2}(25.1 \%-38.4 \%)$ and $\mathrm{Al}_{2} \mathrm{O}_{3}(27.4 \%$ $-33.6 \%$ ) are the most the concentrated elements in the studied materials. These concentrations involve the high 
amounts of kaolinite $(48.29 \%-65.1 \%)$ and gibbsite $(8.26 \%$ - 16.54\%). Moreover, the amounts of FeO $(10.1 \%$ $20.7 \%)$ associated to $\mathrm{TiO}_{2}(1.7 \%-4.2 \%)$ are related to hematite $(16.62 \%-17.40 \%)$ (only in reddish facies) and ilmenite $(3.23 \%-7.98 \%)$ and goethite $(9.64 \%)$ (only in yellowish facies). These minerals compositions show that the Bafang fine soils are closed to the ferrallitic soils (Tematio et al. 2009). The presence of gibbsite in lateritic fine materials is related to tropical humid climate (Tassongwa et al. 2017). In this climate condition, there exists the hydromorphic environment, identifying by the orange yellow (10YR7/8) mineral horizon due the presence of ferric hydric mineral as goethite evaluated at $9.64 \%$ proportion. However, Kamtchueng et al. (2015); Nzabakurikiza et al. (2016) and Onana et al. (2017) attest that goethite mineral is linked to equatorial zone. The rates of quartz $(1.92 \%-7.02 \%)$ are lower than those registered on lateritic soils developed on migmatitic rock (Nzabakurikiza et al. 2016) and lateritic soils developed on granite and sandstone in savannah area (Millogo et al. 2008). Therefore, the low amount of quartz denotes that the Bafang fine soils derived from mafic geological formation. The presence of plagioclase in relic form specifies that the studied materials come from the basaltic rocks because they are widespread in the Bafang area (Tchuimegni et al. 2015). This petrographic type contains a lot of ferromagnesian minerals where come from the minerals phases as hematite, ilmenite and goethite by weathering degradation. The degree of leaching of the studied materials is highlighted by the depletion of alkaline and calco alkaline elements: $\mathrm{Ca}, \mathrm{Na}, \mathrm{K}, \mathrm{Mg}$; and testify the presence of Illite $(1.99 \%-2.65 \%)$, montmorillonite $(0.90 \%$ only in LA 1$)$ and plagioclase $(0.69 \%)$. The materials LA2 and LA3 are more leached than the LA1 and the responsible process of their formation is moderate lateralization which prevails over the tropical area (Schellemann, 1983) (Fig. 11). The same weathering process is observed on mottled mineral horizon of Balkouin lateritic profile in savannah area (Giorgis et al. 2014). Furthermore, the silica/sexquioxide $(\mathrm{S} / \mathrm{R})$ values derived from $\mathrm{SiO}_{2}-\mathrm{Al}_{2} \mathrm{O}_{3}-\mathrm{Fe}_{2} \mathrm{O}_{3}$ (Wt. \%), are 1.3 and 1.6 (Table 1). These values belong to $1.33<\mathrm{S} / \mathrm{R}<2$ range which were obtained on 0-20 mm particles size class and they represent the lateritic materials (Autret 1983). However, the S/R values obtained on particles less than $0.2 \mathrm{~mm}$ in size, prove that the Bafang lateritic fine soils have higher amount of $\mathrm{Fe}_{2} \mathrm{O}_{3}$ and $\mathrm{Al}_{2} \mathrm{O}_{3}$ contents in hematite, goethite, gibbsite ilmenite; when, Issiakou et al. (2015) have proved that these minerals phases are concentrated mostly in nodules particles.

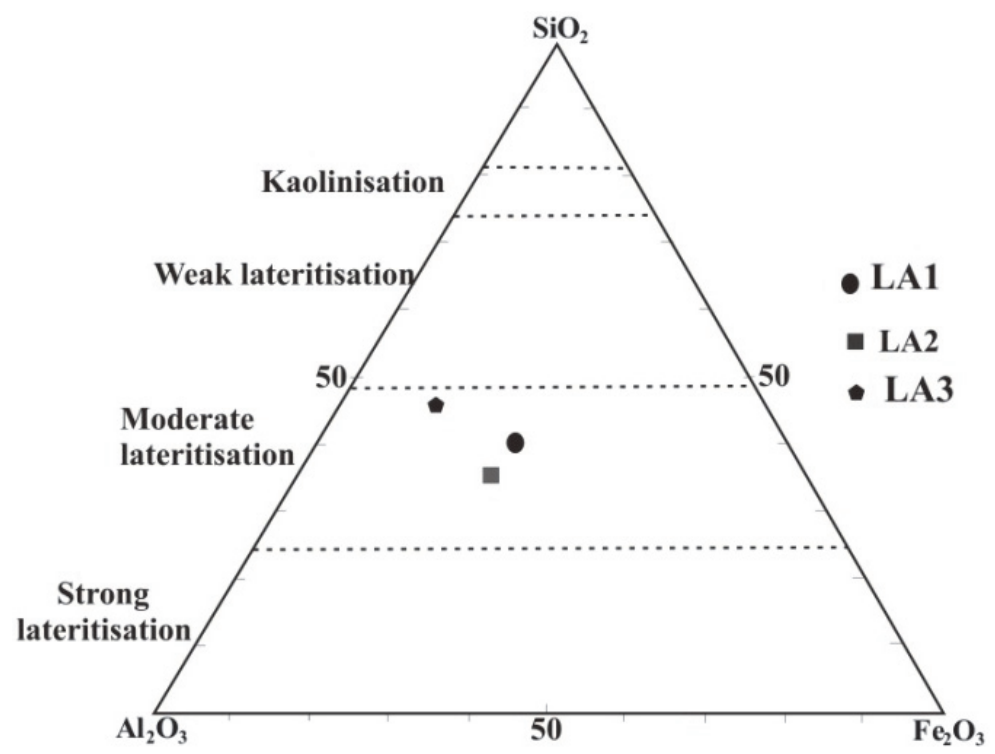

Figure 11. Position of Bafang lateritic fines soils in $\mathrm{SiO}_{2}-\mathrm{Al}_{2} \mathrm{O}_{3}-\mathrm{Fe}_{2} \mathrm{O}_{3}$ (Wt. \%) ternary diagram (Schellemann, 1983)

\subsection{Geotechnical and Mechanical Properties}

The studied lateritic fine soils have light specific density values $\left(26.6 \mathrm{KN} / \mathrm{m}^{3}-26.8 \mathrm{KN} / \mathrm{m}^{3}\right)$. They are loose materials rich of particles less than $0.2 \mathrm{~mm}$ in size, despite their minerals phases content like hematite, ilmenite, gibbsite and goethite which are responsible to heavy specific density of materials. These specific density values are lower than those observed on lateritic gravelly soils by Nzabakurikiza et al. (2016); Onana et al. (2017) and are similar to those obtained on clayey laterite by Kamtchueng et al. (2015). Concerning the Atterberg limits, the high trend of liquid limit (67.4\% mean) and plasticity limit ( $42.6 \%$ mean) of reddish facies seems to be due to the presence of montmorillinite in addition to kaolinite and illite. Also, the rate of organic matter in the LA1 material which is $9.4 \%$ (Tab. 3), participates actively to increase the liquid limit and plasticity limit (Hamouche and Zentar, 
2016). Meanwhile, the plasticity index value of reddish facies is less than the one of yellowish facies. This is due to the high amount of kaolinite in yellowish facies than the reddish facies. Therefore, the plasticity index values are $24.8 \%$ (average) for reddish facies and $23.8 \%$ for yellowish facies and belong to plasticity range $12-25 \%$. The organic matter proportions are 5.04\% $-9.4 \%$ and the degree of activity of fine particles is low $0.03-0.09$. According to the specification XP P94-011 (1999), the studied materials are none organic; inactive, solid in term of consistence and less plastic. The figure 12 shows that the Bafang lateritic fine soils are medium swelling to high swelling materials. Accoding to Prian et al. (2000), these materials are moderately swelling materials. Even more, they are moderate clayey to clayey materials and are plastic (yellowish facies) and very highly plastic (reddish facies) (Fig. 13). These degrees of plasticity corroborate to those of gravelly lateritic soils preconizing for subbase course (Kamtchueng et al. 2015; Mvindi et al. 2017; Nzabakurikiza et al. 2016; Onana et al. 2017). By combining the grains size distributions and Atterberg limits and both of them with methylene blue values on the other hand, the studied materials are A class and A-7-6 sub-group based respectively on French GTR specification and US HRB specification.

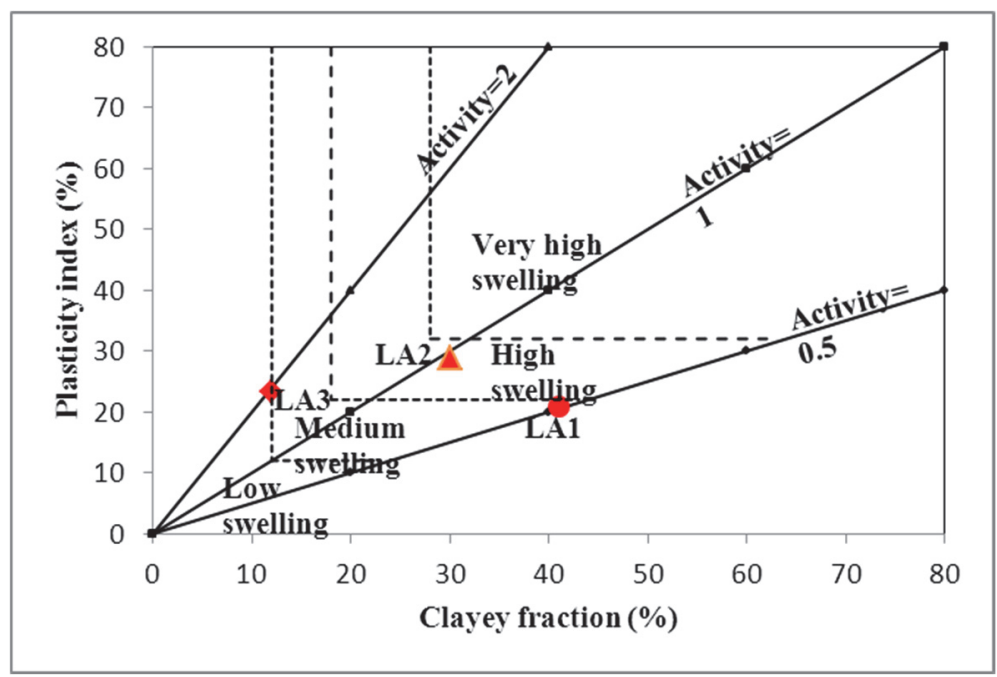

Figure 12. Position of Bafang lateritic fine soils in potential expansiveness of (Williams et Donaldson, 1980)

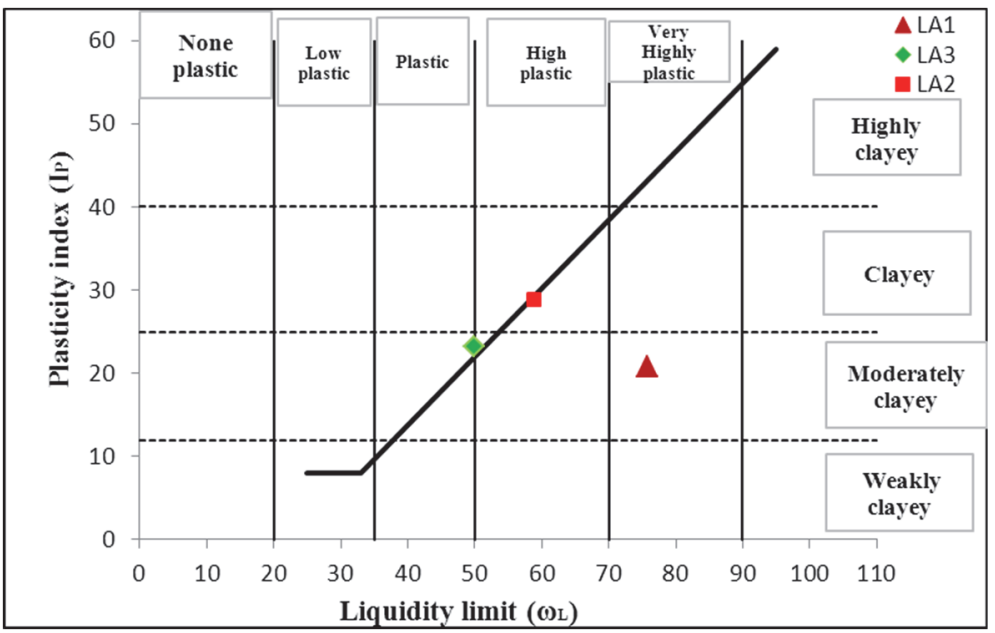

Figure 13. Position of studied materials in Casangrande diagram, modified by Jones and Holtz (1973) and Dakshanamurphy and Raman (1973) on the other hand

The MDD values fluctuate between $15.4 \mathrm{KN} / \mathrm{m}^{3}$ and $16.7 \mathrm{KN} / \mathrm{m}^{3}$. They are light and moderate dense materials respectively (XP P94-011, 1999). The abundance of kaolinite and especially the hematite, ilmenite, goethite and gibbsite concentrated in grain size less than $0.2 \mathrm{~mm}$ on the other hand, explain the density degree. This involves the high values of OMC which varies from $25.3 \%$ and $26.1 \%$. However, the low MDD values and the high values of Bafang fine lateritic soils are opposite to those of gravelly lateritic soils observed in equatorial zone (Zame et 
al. 2017). The IBR and CBR values are deduced from compaction parameters (MDD and OMC). Thus, the IBR values are more than $40 \%$. The IBR values drop drastically with the increasing of the rate of moisture content. This is the proof that the fine lateritic soils can only be used in the drained condition. However, these studied materials have the IBR values more than $40 \%$; hence they are materials able to ensure the durability of the pavement as embankment materials (Gregroire 2011). Furthermore, the CBR values fluctuate from 22 to 25 . They are in accordance with S4 bearing class (CEBTP, 1984) and are similar to some lateritic materials studied by Kamtchueng et al. (2015). These IBR and CBR values could be related to their high degree of consistence (solid or firmness) and compactness, which seem to be due to the higher amount of kaolinite mineral phase content (53.34\% for LA1 and $65.1 \%$ for LA3). For Onana et al. (2017), the compactness property of materials is linking to their amount of clays minerals. Nonetheless, they cannot be recommended for sub-base course of pavement road (Millogo et al. 2008; Nzabakurikiza et al. 2016; Mvindi et al. 2017; Onana et al. 2017). According to Sikali and Mir Emerati (1986) and CEBTP (1984), their CBR values correspond to the materials used for drained embankment. For the unconfined compressive strength, the values obtained on lateritic fine soils, move from 1.7 MPa to 4.5 MPa. These values are higher than the unconfined compressive values range (0.5-1.5 MPa) reported by Messou (1980), which correspond to lateritic materials preconized for sub base course. Millogo et al. (2008), Nzabakurikiza et al. (2016) and Onana et al. (2017) have highlighted that the unconfined compressive strength ranges values for suitable sub-base course lateritic gravel soils are $1.26 \mathrm{MPa} ; 1.22-1.28 \mathrm{MPa} ; 0.88-1.2 \mathrm{MPa}$ respectively. On the other hand, the indirect tensile strength values are from $0.17 \mathrm{MPa}$ to $0.26 \mathrm{MPa}$. These indirect tensile strength values are more resistant than those for equatorial zone lateritic gravel (0.09-0.15 MPa) (Onana et al. 2017) and for savannah zone (Millogo et al. 2008). Whereas, the indirect tensile strength values of Bafang fine lateritic soils are less than indirect tensile strength values (0.80-0.84 MPa) reported by Nzabakurikiza et al. (2016). Therefore, the studied materials have unconfined compressive strength and indirect tensile strength correspond to the materials suitable for road embankment.

\section{Conclusion}

The present study aims to show the relationship between geotechnical parameters and the minerals phases compositions in order to better understand the behavior of the Bafang fine lateritic soils and their better use as embankment materials on the other hand. It appears that:

(1) The Bafang fine lateritic soils are materials which appear under two mains facies on macroscopic plan: the reddish facies and the yellowish facies. These facies have mineral horizons which are at least $78 \mathrm{~cm}$ in thickness.

(2) On chemical and mineralogical point of view, the kaolinite is the main minerals of the two facies, with at least $53.34 \%$ in term of amount and the illite and montmorillonite represent the accessory minerals in term of proportion. The minerals remain are oxides (hematite, ilmenite), hydroxide (gibbsite), oxihydroxide (goethite) and silicate (plagioclase and quartz). The plagioclase relic, the little amount of quartz and the abundance of oxides, hydroxide and oxihydroxide minerals on the other hand, show that the studied materials derived mafic volcanic rock under the tropical humid climate condition. Due to the predominance of $\mathrm{Fe}_{2} \mathrm{O}_{3}$ and $\mathrm{Al}_{2} \mathrm{O}_{3}$ on $\mathrm{SiO}_{2}$, the $\mathrm{S} / \mathrm{R}$ values are less than 1.6 and prove that the Bafang fine soils are moderate laterite.

(3) On the geotechnical plan, the Bafang lateritic fine soils are fine loose materials according to GTR and HRB. The reddish facies has higher amount of fine particles (98.5\%) than the yellowish facies (72\%). They are plastic and moderately swelling materials. Despite their optimum moisture content which are $25.3 \%$ (reddish facies) and 19.9 (yellowish facies), these materials are respectively light dense and moderate dense. They are resistant materials because the IBR and CBR values are $49 \%$ and $22 \%$ respectively for the reddish facies while the IBR and CBR values for the yellowish facies are respectively $54 \%$ and $25 \%$. Concerning the mechanical properties, the minimum unconfined compressive strength and the tensile strength values are respectively $1.7 \mathrm{MPa}$ and $0.17 \mathrm{MPa}$ at least at $25.3 \%$ of moisture content.

(4) According to IBR, CBR, UCS and Rt values, the studied material is preconized as embankment materials road but inder drained condition. Meanwhile the future study aims to investigate the mechanical behavior under the different conditions like unconsolidated undrained, unconsolidated drained and consolidated drained.

\section{Acknowledgment}

The authors thank the French Government through the Service de Cooperation et d'Action Culturelle (SCAC) of France Ambassy in Cameroon for sponsoring this work. Moreover, we address our gratitude to Bernard TASSONGWA for the revision of the mineralogical percentages calculation.

\section{References}

Autret, P. (1983). Latérite et graveleux latéritiques. L C P C, 38p. 
Camapun, de Carvalho, J., Rezende, L. R. D., Cardo, F. B. D. F., Lucena, L. C. D. F. L., Guimarães, R. C., \& Valencia, Y. P. (2015). Tropical soils for highway construction: Pecularities and Considerations. Transp Geotech, 5, 3-19. https://doi.org/10.1016/j.trgeo.2015.10.004

CEBTP. (1984). Guide pratique de dimensionnement des chaussées des pays tropicaux. Ministère de la coopération de la république française. $155 \mathrm{p}$

Dakshanamurphy, V., \&Raman, V. (1973). A simple method of identifying an expansive soil. Soils and foundations, Japanese Soc. Soil Mech. And Foundation Ing., 13(1),97-104.

Giorgis, I., Bonetto. S., Guistetto, R., Lawane, A., Pantet, A., Rossetti, P., Thomassin, J. H., \& Vinai, R. (2014). The lateritic profile of Balkouin, Burkina Faso: Geochemistry, mineralogy and genesis. J. Afr. Ear. Sci., 10, 31-48. http://dx.doi.org/10.1016/j.afrearsci.2013.11.006

Gregoire, C. (2011). Traitement de sols de remblais, fonds de coffret et sous fondation. Transparents de présentations du Service Public de Wallonie.

Hajjaji, M., Kacim, S., Alami, A., El Bouadili, A., \& El Mountassir, M. (2001). Chemical and mineralogical characterization of a clay taken from the Moroccan Meseta and a study of the interaction between its fine fraction and Methylene blue. Applied Clay Science, 20, 1-12.

Hamouche, F., \& Zentar, R. (2016). Influence de la matière organique sur les propriétés physiques des sédiments de draguage. Poster, $34^{\text {ème }}$ Rencontres Universitaires de Génie Civil.

Hyoumbi, T. W., Wouatong, A. S. L., Pizette P., Abriak, N. E, \& Medjo, E. R. (2017). Assessment of laterite suitable for road construction in Bafang Area (West-Cameroon) based on physical properties, geoenvironmental factors and GIS software. JMEST, 4, 6815-6829. ISSN: 2458-9403.

Jones, D. E., \& Holtz, W. G. (1973). Expansive soils-the Hidden disaster.Civil Engineering, 43(8), 49-51.

Kamtchueng, T. B., Onana, V. L., Fantong, Y. W., Ueda, A., Ntouala, F. D. R., ... Ondoa, J. M. (2015). Geotechnical, chemical and mineralogical evaluation of lateritic soils in humid tropical area (Mfou, Central-Cameroon): Implications for road construction. I. J . Geo-Eng., 1-21., https://doi.org/10.1186/s40703-014-0001-0

Leumbe, L. O., Bitom, D., Tematio, P., Temgoua, E., \& Lucas, Y. (2005). Etude des sols ferrallitiques à caractères andiques sur trachytes en zone de montagne humide tropicale (Monts Bambouto - Ouest Cameroun). Etude et gestion des sols, Vol. 12 pp.323-326.

Magnien, R. (1980). Manuel pour la description des sols sur le terrain. ORSTOM, Paris, 99 p.

Mahalinga-Iyer, U., \& Williams, D. J. (1997). Properties and performance of lateritic soil in road pavements. Eng. Geol., 46, 71-80.

Mefire, N. A., Njoya, A., Yongue, F. R., Mache, J. R., Tapon, N. A., Nzeukou, N. A., ... Fagel, N. (2015). Occurrences of kaolin in Koutaba (west Cameroon): Mineralogical and physic-chemical characterization for use in ceramic products. Clay Minerals, 50, 593-606.https://doi.org/10.1180/claymin.2015.050.5.04

Messou, M. (1980). Comportement mécanique d'une couche de base en graveleux latéritiques améliorés au ciment: Cas des routes en Côte d'Ivoire. Thèse de Doct-Ing en Génie Civil à l'Ecole Nationale des Ponts et Chaussées Paris. 197p.

Millogo, Y., Traoré, K., Ouedraogo, R., Kaboré, K., Blanchart, P., \& Thomassin, J. H. (2008). Geotechnical, mechanical, chemical and mineralogical characterization of a lateritic gravel of Sapouy (Burkina Faso) used in road construction. J. Construction and Building Materials, 22, 70-76. https://doi.org/10.1016/j. conbuildmat

Munsell Color Charts (1975). Color Guides. Baltimore Md: Handbook manual, $34 \mathrm{p}$.

Mvindi, N. T. A., Onana, V. L., Ngo'o Ze, A., Ohandja, N. H. T., \& Ekodeck, E. G. (2017). Influence of hydromorphic condition in the variability of geotechnical parameters of gneiss-derived lateritic gravels in a savannah tropical humid area (Center-Cameroon) for road construction purposes. Transportation Geotechnics, 12, 70-84. https://doi.org/10.1016/j.trgeo. 2017.08.003

NF P 94-420 (2000). Roches. Détermination de la résistance à la compression uniaxiale. AFNOR, 7p.

NF P 94-422 (2001). Détermination de la résistance à la traction-méthode indirecte - Essai brésilien. AFNOR, 7p.

NF P94-051 (1993). Reconnaissance et essai de détermination des limites d'Atterberg. AFNOR, 15p.

NF P94-078 (1997). Sols : Reconnaissance et essais indice CBR après immersion-indice CBR immédiat-indice 
portant immédiat. AFNOR, 12p.

NF P94-093 (1999). Détermination des références de compactage d'un matériau. AFNOR, 18p.

NF P98 232-3 (2001). Tests relating to pavement - determination of the mechanical characteristics material bound with hydraulic binders - Part 3: Diametral compression test on hydraulic and pouzzolanic binder bound materials. AFNOR, $12 \mathrm{P}$.

Norme NF P94-068 (1998). Mesure de la capacité d'absorption de bleu de méthylène d'un sol ou d'un matériau rocheux. AFNOR, $8 \mathrm{p}$

Nzabakurikiza, A., Onana, V. L., Ngo'o Ze, A., Mvindi, N. T., \& Ekodeck, E. G. (2016). Geological, geotechnical and mechanical characterization of lateritic gravels from eastern Cameroon for road construction purposes. Bull. Eng. Geol. Environ, 76, 1549-1562. https://doi.org/10.1007/s10064-016-0979-y

Onana, L. V., Ngo’o Ze, A., Medjo, E. R., Ntouala, R. F. D., Nanga, B. M. T., Owoudou, N. B., \& Ekodeck, G. E. (2017). Geological identification, geotechnical and mechanical characterization of charnockite-derived lateritic gravels from Southern Cameroon for road Construction purposes. Transportation Geotechnics, 10, 35-46. https://doi.org/10.1016/j.trgeo.2016.12.001

Prian, J. P., Donsimoni, M., Vincent, M., Denis, L., Gallas, J. C., Marty, F., \& Motteau, M. (2000). Cartographie de l'aléa retrait-gonflement des argiles dans le département de l'Essonne, Rapport BRGM nRP-50376, 269.

Schellmann, W. (1986). A new definition of laterite. Geol. Surv. India, Mem., 120, 1-7.

SETRA-LCPC. (2000). Réalisation des remblais et des couches de forme. $2^{\mathrm{e}} \mathrm{Ed}, 211 \mathrm{p}$.

Sikali, M. E .(1986). Utilisation des latérites en techniques routières au Cameroun. Acte du séminaire régional sur les latérites : Douala-Cameroun,277-288.

Tassongwa, B., Eba, F., Njoya, D., Tchakounte, N. J., Jeudong, N., Nkoumbou, C., \& Njopwouo, D. (2017). Physico-chemistry and geochemistry of Balengou clay deposit (West Cameroon) with inference to an argillic hydrothermal alteration. C. R. Geoscience, 11p. https://doi.org/10.1016/j.crte.2017.06.002

Tchuimegnie, N. B. N., Kamgang, P., Chazot, G., Agranier, A., Bellon, H., \& Nonnotte, P. (2015). Age, geochemical characteristics and petrogenesis of Cenozoic intraplate alkaline volcanic rocks in the Bafang region, West Cameroon. Journal of African Earth Sciences, 102, 218-232. https://doi.org/10.1016/j.afrearsci. 2014.10.011

Tematio, P. (2005). Etude cartographique et Pétrologique des sols à caractères ferrallitiques et andosoliques dans les monts Bambouto (Ouest-Cameroun) : influence de la lithologie et des facteurs du milieu sur la nature et la distribution des sols en région de montagne tropicale humide. Thèse Doct. Etat, Fac. Sci. Univ. Ydé I, 252 p.

Tematio, P., Fritsch, E., Hodson, M. E., Lucas, Y., Bitom, D., \& Bilong, P. (2009). Mineral and geochemical characterization of a leptic aluandic soil and a thapto aluandic-ferralsol developed on trachytes in Mount Bambouto (Cameroon volcanic line). Geoderma, 152, 314-323. https://doi.org/10.1016/j.geoderma. 2009.05.029

Thiry, M., Carrillo, N., Franke, C., \& Martineau, N. (2013). Technique de préparation des minéraux argileux en vue de l'analyse par diffraction des Rayons $\mathrm{X}$ et introduction à l'interprétation des diagrammes. Rapport technique $\mathrm{N}^{\circ} \mathrm{RT} 131010 \mathrm{MTHI}$, Centre de Géoscience, Ecole des Mines de Paris, Fontainebleau, France, 34P.

Wang, H., Li, C., Peng, Z., \& Zhang, S. (2011). Characterization and thermal behaviour of kaolin. Journal of Thermal Analysis and Calorimetry, 105, 157-160.

Williams, A. B., \& Donaldson, G. W. (1980). Developments related to building on expansive soils in soils South Africa: 1973-1980. Proc. $4^{\text {th }}$ Int. Conf. on Expansive Soils, Denver,2,834-844

XP P94-011 (1999). Description - Identification - Dénomination des sols. AFNOR, 18P.

XP P94-047 (1998). Détermination de la teneur pondérale en matière organique d'un matériau. AFNOR, 6P.

Yoder, E. J., \& Witczak, M. W. (1975). Principles of pavement design. Wiley interscience publication (2nd ed), USA. 711p.

Yvon, J., Lietard, O., \& Cases, J. M. (1982). Mineralogie des argiles kaoliniques des charpentes. Bull. Mineral, 105,431-437.

Zame, Z. P., Assomo, S. P., \& Onwualu, N. J. (2017). Assessment of geotechnical properties of lateritic gravels 
from South-Cameroon road work. International Journal of Geosciences, 8, 949-964. https://doi.org/10.4236/ijg.2017.88054

\section{Copyrights}

Copyright for this article is retained by the author(s), with first publication rights granted to the journal.

This is an open-access article distributed under the terms and conditions of the Creative Commons Attribution license (http://creativecommons.org/licenses/by/4.0/). 